\title{
Recreating an American Myth: An Analytical Reading of Paul Bunyan by W. H. Auden and Benjamin Britten
}

\author{
Alexander Chih-Yuan Mai \\ Correspondence: College of Foreign Studies, Kansai Gaidai Univeristy, Osaka, 16-1 Nakamiyahigashino-cho, Hirakata \\ City, Osaka 573-1001, Japan. E-mail: acmai@kansaigaidai.ac.jp
}

Received: May 4, 2019 Accepted: July 10, 2019 Online Published: July 17, 2019

doi:10.5539/res.v11n3p26

URL: https://doi.org/10.5539/res.v11n3p26

\begin{abstract}
One of the ability which music possesses is to evoke the audience's sense of cultural and national identity. In the second half of the twentieth century, people can easily travel and relocate to a new country in order to search for a better living condition. However, with this newly found freedom, people's sense of belonging and cultural identity has been put into serious doubts and tests. W. H. Auden and Benjamin Britten's Paul Bunyan encapsulates and foresees this phenomenon. Both have just arrived at the United States to escape from the war-torn Britain. Eager to find a voice to suit their new audience and symbolically swear allegiance to their newly adopted country, Auden and Britten employed an American founding myth in order to engage with their American patrons. Through a closed reading of Paul Bunyan, listeners will soon realize the inseparable notions between the musical presentation and its cultural identity. Furthermore, the story is told in the form of American musical theater, which is the artists' ambitious attempt to capture the American optimism and spirit. This article intends to explore the notion of "myth narrative" in the genre of Music Theater; and how it reflects both the poet and the composers' intention to obtain their sense of American identity.
\end{abstract}

Keywords: national identity, immigration, opera libretto, mythic narrative, W. H. Auden

\section{Introduction}

W. H. Auden and Benjamin Britten's only operatic collaboration, Paul Bunyan fully expands an American ancestral folklore on the formation of the United States of America. The opera explores the function of a secular myth. By telling the story of Paul Bunyan and his mission to help the pioneers in establishing the American identity, the work modernizes this well-known myth and brings a new social and political dimension to the story. The operetta invites us to take fresh look into the American founding myth and gives the readers a sense of national unity and optimism against the upraising of social populism and political opportunism.

In the operetta's final passage as the mythical giant bids farewell to his beloved people, whom he nurtured and encouraged for the establishment of a new independent country. "You and I must go our way;/ I have but one word to say.../ As at freedom's puzzled feet/ Yawn the gulfs of self-defeat; / All but heroes are unnerved/ When life and love must be deserved." (Auden, 1988) The poet and the composer have taken the audience through a journey of self-discovery, a discovery of its national identity. While Paul Bunyan establishes the foundation of the American spirit; Auden and Britten also express their joint aspirations in coming to the new continent through the creation of the operetta. The opus was the first major public engagement for both the librettist and the composer since their arrival in America and they were keen to demonstrate their ambition by presenting their version of "the American "voice"" (Mitchell, 1988).

The setting of the operetta is largely symbolical and the librettist utilizes it as a narrative device in restructuring the mythic folklore. Auden rewrote the myth not only to fulfill his quest of exploring American identity but also to project his ideas about nationhood into a theatrical form. Furthermore, the librettist sincerely hoped to gain recognition from his newly adopted country (White, 1983). As a result, Paul Bunyan was finally presented in the form of a musical drama and was given its premiere in a student production by the Theatre Association of Columbia University, New York.

Its composition is strongly tied in with its librettist's personal experience, fulfilling his wish to write a piece on the subject of "America" after he and Christopher Isherwood first arrived in the new world. To quote Nicholas Jenkins' words, “Auden's initial ideas about the United States had emphasized its approximation to the truly 'open society' as opposed to the 'closed', backward-looking societies of Europe." (Jenkins, 2004) The theme of Paul Bunyan echoed Auden's expectation, which was to seek out the spirit of the American identity and to elaborate the founding myth of America. 


\section{Recreating an American Myth}

The legend of Paul Bunyan perfectly suited Auden's intention in recreating an American myth. The tale concerns with a giant who leads his immigrant pioneer followers in an exploration of the Promised Land, their new country. Through this exploration he inspires the formation of the American identity (Seymour, 2004). His giant figure symbolizes the boundless territory of America. His spirit, when presented aurally on stage, leads the audience to imagine the supernatural power and the characteristics of Paul Bunyan. This theatrical mechanism directly leads the spectators into associating the giant figure as the guardian of this newly established nation, and capturing its national spirit. Paul Bunyan's surrounding human characters are presented as loggers and farmers, who work with their bare hands. These characters also symbolize as sons of the soil who would naturally form an attachment with their land.

Auden's idea, of presenting the essential meaning of "America" through pioneering immigrants, echoes the eighteenth-century American writer, J. Hector St. Jean de Crèvecoeur's writing, Letters from an American Farmer which appeared in 1782. Its publication, which came after the American Revolution, had satisfied the public's growing desire to express their sense of American identity. Crèvecoeur reflects that "he [an American] must greatly rejoice that he lives at a time to see this fair country discovered and settled; he must necessarily feel a share of national pride, when he views the chain of settlements which embellishes these extended shores." (Crèvecoeur, 1904)

Auden's Paul Bunyan not only shares the same sentiment but also gives a more flexible point of view, in regard to the forthcoming nation, through the voice of the mythical giant. "Every day America's destroyed and re-created, / America is what you do, / America is I and you, / America is what you choose to make it." (Auden, 1988) The passage in fact is directly addressing to the audience and intends to inspire them in participating in this national myth. Furthermore, the stanza also reflects the nation's strong sense of self confidence. With the sequential use of pronouns, Bunyan in fact is encouraging the American people to feel optimistic and more self-assured about their country's future. The recurrence of the word, "America" demands the repetition of "am", the first person singular of the verb 'to be'; in this way, Auden indicates the new nation would gradually evolve into a united community.

Paul Bunyan's final statement can also be read as Auden's personal view for the establishment of the American identity. For him, it is not the land that contributes to the people's vision of their ideal world, it is the people themselves who establish the foundation of America, and they construct the nation according to their dreams. In this piece, apart from Paul Bunyan who sets up the logging team, everyone has his own expectation of the enterprise, and the opus concludes with a happy ending, in which all of the main characters have a better place to be, thus enabling them to fulfil their individual talents and dreams.

\section{The Setting and Characters}

The setting of Paul Bunyan is strongly symbolic. The piece is entirely set in a forest. The trees in the prologue reflect the regeneration of the new continent over the past centuries. The singing trees therefore symbolize the untamed nature as they are waiting for the pioneers to explore its resources in order to establish a new nation. The symbolism, which Auden uses, is clearly intended to give the opera a mythic quality. According to the librettist's observation, "America is unique in being the only country to create myths after the occurrence of the industrial revolution. Because it was an undeveloped continent with an open frontier and a savage climate, conditions favorable to myth-making still existed (Auden, 1988)." This grand enthusiasm for depicting the formation of the nationhood is reflected in the Prologue, where the old trees not only embody the mythic characteristic of the opera but also describe the inevitable emergence of the country. "Since the birth/ Of the earth/ Time has gone/ On and on: / Rivers saunter, / Rivers run, / Till they enter/ The enormous sea, / Where they prefer to be." The Prologue also sets the foundation for the following acts - building up a raw atmosphere for the characters to explore and cultivate (Whittall, 1982). The grand scale of the prologue from the piece can even stand comparison with Richard Wagner's Das Rheingold: Vorabend des Bühnenfestspiels «Der Ring des Nibelungen» (1869), in that Auden succeeds in drawing a complete picture of the events which will unfold in the opera itself.

Both Das Rheingold and Paul Bunyan begin with the image of a flowing river. The two works suggest that nature is the cradle for all living beings and that a harmonious condition would ensure national prosperity. Furthermore, the two operas are dealing with a founding myth. While Das Rheingold illustrates the formation of the world's order, Paul Bunyan depicts the creation of the new world of America. From both the literary and musical perspective, the Prologue from Paul Bunyan is less complex than Das Rheingold, but the librettist's ambition to achieve a mythical element in an epic scale is unmistakable (Carpenter, 1981).

Bunyan's final verse reveals the protagonist's acknowledgement of his own achievement and further expresses his intention in transferring the responsibility of nationhood building to its own people. The phrase, "All I had to do is done, / You remain but I go on" vividly expresses the giant's satisfaction of the mission; the passage also depicts the hero's determination in urging his fellow lumberjacks to create their own future. In this way, Bunyan's farewell not only 
leads to the establishment of an autonomous state but also encourages this newly formed nation to forge its own national characteristics. In Paul Bunyan, the giant will not indulge himself in basking in the glory of what he has already achieved; he must surrender his personal interest in order to establish the stability of the new nation. His final farewell to his beloved pioneers suggests not so much as an ultimate departure but as a benevolent gesture in prompting them to create their own future without his guidance. All these optimistic national characteristics, which are captured by Auden, are meant not only to enhance the audience's self confidence in being American but also to represent the poet's determination to intergrade with America, the country he is so eager to be identified with at the time (Clark, 1995).

The legend of Paul Bunyan appears to have originated from several lumberjack tales, which may have been passed down for generations. The story had never been heard outside the haunts of the lumberjack until it first appeared in printed form in 1914. According to W. B Laughead's study, "the best authorities never recounted Paul Bunyan's exploits in narrative form. They made their statements more impressive by dropping them casually, in an offhand way, as if in reference to actual events of common knowledge... With painful accuracy they established the exact time and place, 'on the Big Onion the winter of the blue snow' or 'at Shot Gunderson's camp on the Tadpole the year of the sourdough drive.' They elaborated on the old themes and new stories were born in lying contests where the heights of extemporaneous invention were reached." (Laughead, 1934, p.15-16) The appearance of the Bunyan myth is itself a symbol of America's growing sense of national identity in the early twentieth century.

By employing the Bunyan myth, Auden can therefore channeling his American audience's sense of national identity into his very first operatic opus. Paul Bunyan's mythical aspect also provides the English poet an opportunity to translate a celebrated story into the format of music theatre. In a mythic narrative, a story does not require a realistic setting; furthermore, symbols can function as a binding feature to unite otherwise various elements into its plot. In Paul Bunyan, for example, the giant is a symbol of the force of nature which assists and encourages the pioneers to build a new nation. The roles of the bookkeeper, Johnny Inkslinger and the foreman, Hel Helson are well contrasted characters among Bunyan's lumberjacks. Inkslinger represents a person with intelligence while Helson embodies a man with raw physical strength. Inkslinger's song contains rich cultural and literary references and its witty and amusing lines are well suited to the bookkeeper's character. On the other hand, Helson has not been given any solo aria but has been featured in various vocal ensembles demonstrating the librettist's intention to show that the role is heavily reliant on the co-operation of the others. "Helson the Brave" and "Helson the Strong" have further underlined his robust reputation.

The bookkeeper, Johnny Inkslinger, who originally surrendered to Paul Bunyan's request and agreed to join the team because of his need for a constant food supply, finally receives an invitation from Hollywood to work as a technical adviser. The Swedish foreman, Hel Helson, whose vacillating character was tamed by Paul Bunyan, eventually joins the Administration in Washington. The good cook, Slim, who had set off to explore the world, finds his true love, Tiny, Paul Bunyan's daughter; and ultimately finds a position, managing a hotel in mid-Manhattan. While the characters' diverse destiny exposes the inconsistency in the time scheme in the opera, the detachment from real time is, in fact, what the librettist aiming for. Through the juxtaposition of various American institutions in different periods, Auden's work transcends the audience's lineal concept of history and creates a mythic frame. As a result, in Paul Bunyan, "America" signifies various things, according to the dreams of each individual that their aspirations will eventually to be materialized in this Promised Land (Mitchell, 1988).

\section{Musical Theater and the American Identity}

Auden's decision to employ the style of musical theatre as the narrative form for Paul Bunyan also demonstrates his enthusiasm to gain recognition from the American public. Influenced as he was by dynamic artistic activities, especially the burgeoning of theatre, film and radio in the thirties and following on from having written a series of songs with the collaboration of Benjamin Britten, it must have seemed the logical next step for Auden to write a full-length musical theatre piece to celebrate the American spirit (Evans, 1979). This fulfilled his desire to write an American piece, a wish which dated back to his arrival there. A "Broadway" style piece formed the basis of the project, even though Paul Bunyan premiered at Columbia University. Donald Mitchell reports "though a Broadway first night may not have materialized, and whether or not one concludes that it was a sensible or realistic ambition in the first place, there can be no denying that the Broadway idea (or goal) had a vital influence on the shaping of Paul Bunyan and was responsible for some of its most prominent features." (Auden, 1988)

By using the existing myth, Auden and Britten intended to interpret the idea of American identity. The story of Paul Bunyan provided the poet and the composer with an appropriate paradigm in which they could detach themselves from European customs and one which would lead them directly into the core of American traditions. Furthermore, the heroic story also supplied Auden and Britten with a narrative structure which enabled them to communicate with their targeted American audience. By re-telling the story of Paul Bunyan, both the poet and composer were not only converting the nation's colonial history into a form of art but also were inviting their audience to confront America's 
past with its present. Paul Bunyan thus represents Auden and Britten's mythopoetic attempt to embrace their new residential nation and an aspect of this embrace was the partial adoption of a distinctive American form, the musical.

By the dawn of the twentieth century, the United States of America had been transformed from a rural, agrarian community into an urban, industrialized society, which welcomed immigrants from a wide variety of countries. The nation's growing political and financial power had also led to its growing involvement in international affairs. The victory of the Spanish-American War of 1898 had prompted America into becoming a major imperialistic nation. However, as being a newly established country, America lacked a national myth which could fully capture the nation's concept in cosmic, social order and further celebrate its shared values and hopes of assimilation. The publication of Paul Bunyan and His Big Blue Ox was intended to fill this gap.

The musical, which is derived from European operetta, is a "major form of popular musical theatre of the 20th century." (Lamb, 1992) According to Andrew Lamb, the musical is "a brand of musical theatre distinct from the operetta [in] the incorporation of contemporary subjects, everyday characters and essentially American style of song and voice production with origins in the vaudeville theatre." (Lamb, 1992) Though the piece is set in a mythically anachronistic period of American history, Paul Bunyan still reflects the contemporary American's optimistic spirits. Human characters in the piece not only mirror the young country's thriving economic development but also echo the origins of its citizens from various backgrounds and with different ambitions, all striving to achieve their personal potential. In order to embody a founding myth of America, Auden wrote the piece in a serious, almost didactic fashion, and even though Paul Bunyan still has traces of the operetta, the tonality of the piece impedes the librettist from making any joke on the subject.

Britten's music for the piece also reflects Auden's intention to capture the "American voice". Musically speaking, the work commences in the style of a Broadway musical production, even though he later modifies this genre and style and even incorporates operatic manners into the composition. The upshot of this is that Paul Bunyan rather lacks a sense of direction with regard to both musical and verbal composition. Britten's first operatic composition is leaning towards musical pastiche which never identifies its dramatic purposes. Auden's verses in the operetta only stand out individually but it is difficult to unite them to form a convincing narrative. Because of this style of writing, the work gives the appearance of being in the form of a musical mosaic - in that it is a compilation of various music theatre traditions rather than a new entity of its own.

Even though both Auden and Britten were superficially following the Broadway style for presenting Paul Bunyan, the work is still categorized as an operetta. This musical genre is as its name indicates - a little opera, which basically is structured with a number of songs to tell a story, just as an opera does. However, operetta tends to employ "light" subjects, such as political satires and romances with spoken dialogue and dances. The music in operetta is highly melodic; these melodic tunes in fact act as stylistic markers which signal to the audience the character of the piece and how it should be "read". Jacques Offenbach's works such as La Belle Hélène (1864) and La Grande Duchesse de Gerolstein (1867) are good examples of this musical genre (Grout \& Williams, 2003). Initially, Offenbach offered programs of two or three satirical one-act sketches, which in turn led to the extension of the format into works of a whole evening's duration and to the establishment of opéra bouffe as a separately identifiable form of full-length entertainment.

In Austria, Johann Strauss, Jr. provided a German version of this popular musical form in the late nineteenth century. He emphasized romantic themes, rather than the satirical manner which is found in the French works of Offenbach. Furthermore, his works relied on dance rhythms, especially the waltz. His collaboration with Carl Haffner and Richard Genée, Die Fledermaus (1874) demonstrates the German operetta style and the work is often performed in a standard opera house. The best known English operettas dating from the late nineteenth century were those written by the collaboration of Gilbert and Sullivan. Their works "owed much to the British theatrical traditions of ballad opera and burlesque and even something to the Victoria choral tradition." (Lamb, 1992) Their works directly influenced the formation and style of the twentieth-century musical. Paul Bunyan contains strong local melody, spoken dialogue and dance rhythms and these characteristics suggest that the appropriate category of the work is operetta.

However, the grand opening of the work reveals its operatic roots. While Paul Bunyan's speeches draw a direct link to the tradition of operetta, the giant's words tend to be more didactic and portentous than an operetta counterpart. On the other hand, the songs and duets apportioned to Slim and Tiny, come straight from the Broadway tradition. Slim's cowboy song also evokes an open-air, rolling prairie-land atmosphere. The boundless field has provided the character with a joyful characteristic and his optimism. As the character fully enjoys the rural life and the company of buffaloes and horses, the desire of obtaining material goods has not corrupted his mind. Slim's song is a forecast of Roger and Hammerstein's Oklahoma! (1943) and Irving Berlin's Annie Get Your Gun (1946) in which the cowboy theme was further woven into the fabric of the musical. 
Inkslinger's song also demonstrates Auden's talent for composing the lyrics in the style of American musical theatre. "In this emergency/ Of so much urgency, / What can I do? / Except wax lyrical? / Don't look satirical; / I have empirical/ Proof I love you." (Auden, 1988) The verbal humor and rhythmic energy has been successfully captured by Auden's words. The entire stanza represents the narrator's unfeigned desire to express his love for Tiny, the daughter of Bunyan. The rapid and yet metrical style of the rhythm is also reminiscent of the manner that Auden was still using his late 1930's poetic style.

However, in Inkslinger's love song, the librettist was preoccupied with its individual poetic style rather than using the verse to further develop the plot or to establish its characterization. Furthermore, as hinted above, this stylistic eclecticism in Paul Bunyan also infects in the music. The "a little of everything" style did not win the critics' approval. Olin Downes criticized the piece in the New York Times on 6 May 1941, "the music seems to wander from one to another idea, without conviction or cohesion." (Mitchell, 1988) Downes' criticism points out that the musical style in the operetta is not united to serve the plot and Britten does not seem to have a concrete idea about its musical direction. As the piece was Britten first major stage work, the lack of experience in musical theatre showed in his tendency, in constructing the operetta, to fall back on the knowledge of writing song-cycles he had gained in the 1930's.

The categorical complexity in Paul Bunyan was probably also increased by the lack of time available to the composer to spend on the project, partly because of the state of his health and perhaps more crucially by his librettist's revisions, which frequently occurred at the last moment. As the project had begun with Auden's idea, Britten tended to compromise between his and the librettist's intentions. It was certainly the case that the extra music usually had to be composed either on the day of rehearsal or the day before (Carpenter, 1981).

This lack of preparation time for Britten seems to have thrown the composer back on to his considerable talent for pastiche. Furthermore, "the limitation and potentialities of the cast" can be considered to have had an influence on the stylistic resources available for the final presentation of the operetta. Mitchell reports that "the concept of communal, workshop theatre was strong at this time, with the implication of opening up the arts to the non-professional (Carpenter, 1981)." Paul Bunyan was, as Britten explained in a letter to his publisher Ralph Hawkes, designed to be "school operetta." Thus, the work was written for performances by unprofessional or amateur performers and this led to the music being written in an approachable manner.

\section{Conclusion}

The lukewarm critical success of the operetta might derive from not only Auden and Britten's inexperience in writing music theater pieces but also, perhaps the inherent difficulty to strike the right balance between these two artistic genres namely, words and music. For the composer, the creation of Paul Bunyan was a bitter experience and he personally viewed the work unenthusiastically, "I feel that I have learned lots about what not to write for the theatre." (Britten, 1992) The most important lesson he took on board, was that he would never allow himself to be dominated by any future librettist. All of his subsequent operas were based on his own ideas and he would only seek a collaborator after he had drawn a blueprint of the proposed project. His librettists would be required to follow his outline in producing text, in other words, the composers wishes were paramount throughout the whole collaboration.

Despite the negative critical reviews, Paul Bunyan was a turning point in Auden's career, especially in terms of his poetic style and content. During the late 1930s and the early 1940s, the poet "ended his long ambivalent flirtation with Marxism, repudiated (though not in every detail) the Freudian image of the self and reclaimed the Christian faith of his childhood." (Jacobs, 1998) One can witness some of these changes in Paul Bunyan. Even though the work emphasizes the collaborative strength of the pioneers who eventually create the nation, the presence of the supra-natural power of Paul Bunyan, suggests other readings to the founding myth of America. Paul Bunyan, despite Auden's desire to be assimilated into the American scene, is still very European. Bunyan has mythic qualities and is frequently morally sententious, but he is entirely without American religiosity. The character remains a fundamentally secular myth of social and political destiny.

\section{References}

Auden, W. H. (1988). Paul Bunyan: The Libretto of the Operetta by Benjamin Britten. London: Faber and Faber, 70.

Carpenter, H. (1981). W. H. Auden: A Biography. London: George Allen \& Unwin Ltd, 261-262.

Clark, T. (1995). Wystan and Chester: A Personal Memoir of W. H. Auden and Chester Kallman. London: Faber and Faber, 95-96.

Crèvecoeur, J., \& Hector, S. J. (1904). Letters From An American Farmer. London: Chatto \& Windus, 48.

Evans, P. (1979). The Music of Benjamin Britten. London: J. M. Dent \& Son Ltd, 133-134.

Grout, D. J., \& Williams, H. W. (2003) A Short History of Opera (4th ed). New York: Macmillan, 378-379. 
https://doi.org/10.7312/grou11958

Jacobs, A. (1998). What Became of Wystan: Change and Continuity in Auden's Poetry. Fayetteville: The University of Arkansas Press, 4.

Jenkins, N. (2004). Auden in America In Stan Smith (Ed.), The Cambridge Companion to W. H. Auden. Cambridge: Cambridge University Press, 51.

Kildea, P. (1984) Britten, Auden and 'Otherness'. In Mervyn Cooke (Ed.), The Cambridge Companion to Benjamin Britten. Cambridge: Cambridge University Press.

Lamb, A. (1992). Musical In Stanley Sadie (Ed.), The New Grove Dictionary of Opera (Vol. 3). London: Macmillan, 525-528.

Laughead, W. B. (1934). The Marvelous Exploits of Paul Bunyan. Doylestown: Wildside Press, 15-16.

Mellers, W. (1984) Paul Bunyan: The American Eden. In Christopher Palmer, The Britten Companion. London: Faber and Faber.

Mitchell, D. (1988). The Origins, Evolution and Metamorphoses of Paul Bunyan, Auden's and Britten's 'American' Opera. In W. H. Auden, Paul Bunyan: The Libretto of the operetta by Benjamin Britten. London: Faber and Faber, 88.

Mitchell, D. (2000). Britten and Auden in the Thirties: The Year 1936. Woodbridge: The Boydell Press.

Seymour, C. (2004). The Opera of Benjamin Britten: Expression and Evasion. Woodbridge: the Boydell Press, 36-37.

White, E. W. (1983). Benjamin Britten: His Life and Operas. London: Faber and Faber, 115-119.

Whittall, A. (1982). The Music of Britten \& Tippett: Studies in Themes \& Techniques. Cambridge: Cambridge University Press.

\section{Copyrights}

Copyright for this article is retained by the author(s), with first publication rights granted to the journal.

This is an open-access article distributed under the terms and conditions of the Creative Commons Attribution license (http://creativecommons.org/licenses/by/4.0/). 